Jurnal Agroteknologi, Vol. 8 No. 2, Februari $2018: 9$ - 14

\title{
KETERSEDIAAN P, SERAPAN P DAN Si OLEH TANAMAN PADI GOGO (Oryza sativa. L) PADA LAHAN ULTISOL YANG DIAPLIKASIKAN SILIKAT DAN PUPUK FOSFAT
}

\author{
(P Availability, $P$ and Si Absorption by Gogo Paddy (Oryza sativa) in Ultisol Field in Which Silicate and \\ Phosphate Fertilizer Applied)
}

\section{ZULPUTRA ZULPUTRA ${ }^{1}$ DAN NELVIA NELVIA ${ }^{2}$}

${ }^{1}$ Dosen Program Studi Agroteknologi Fakultas Pertanian Universitas Pasir Pengaraian

${ }^{2}$ Dosen Program Studi Magister IImu Pertanian Fakultas Pertanian Universitas Riau Email: zulputra53@yahoo.com

\begin{abstract}
The research was conducted from August 2014 to January 2015 in the Ultisol land, Pematang Berangan Village, Rokan Hulu Regency, Riau Province. The study aims to determine the availability of $P, P$ and Si uptake by upland rice plants granting silicate and phosphate fertilizer on Ultisol land. The form of this research is experimental factorial completely randomized design consist of two factors. The first factor is silicate consists of four levels $(0,50,75$, and $100 \mathrm{~kg} \mathrm{SiO} / / \mathrm{ha})$, while the second factor is phosphate fertilizer consists of four levels $\left(0,36,54\right.$, and $72 \mathrm{~kg} \mathrm{P}_{2} \mathrm{O}_{5} / \mathrm{ha}$ ), each combination was repeated three times. The results showed that addition of silicates and phosphates increase the availability of $P, P$ and Si uptake of upland rice crop. Giving of $100 \mathrm{~kg} \mathrm{SiO}{ }_{2}$ and $36 \mathrm{~kg} \mathrm{P}_{2} \mathrm{O}_{5}$ per hectare increase uptake of $P$ and Si, each respectively increased by $208 \%$ and $218 \%$ compared without silicates and phosphates fertilizer.
\end{abstract}

Keywords: Ultisols, silicates, phosphates, upland rice.

\section{PENDAHULUAN}

Ultisol merupakan tanah mineral yang berkembang pada iklim tropik basah dengan curah hujan dan suhu tinggi sehingga mengalami pelapukan lanjut dan pencucian yang intensif. Pencucian terhadap basa-basa dan ion silikat secara intensif menyebabkan tanah bereaksi masam, kejenuhan basa dan kandungan $\mathrm{Si}$ rendah dan kelarutan $\mathrm{Al}$ tinggi sehingga meracun bagi tanaman. (Hardjowigeno, 1993; Subandi, 2007; Makarim et al., 2007).

Jumlah kation $\mathrm{Al}$, $\mathrm{Fe}$ dan $\mathrm{Mn}$ yang tinggi pada Ultisol menyebabkan ketersediaan $P$ menjadi rendah karena $P$ difiksasi oleh ketiga kation tersebut sehingga menjadi faktor pembatas bagi pertumbuhan dan produksi tanaman (Hakim et al., 2008). Kelarutan kation $\mathrm{Al}$, Fe dan $\mathrm{Mn}$ yang tinggi bersifat meracun bagi pertumbuhan tanaman dan merupakan salah satu kendala dalam usaha budidaya padi gogo di lahan Ultisol. Adapun keracunan tanaman oleh kation tersebut menyebabkan pertumbuhan perkembangan akar terhambat sehingga daya serap hara rendah dan berpengaruh terhadap produksi tanaman.

Usaha yang dapat dilakukan dalam meningkatkan ketersediaan $\mathrm{P}$ dan $\mathrm{Si}$ pada lahan Ultisol yaitu dengan pemberian silikat dan pupuk fosfat. Pemberian silikat dapat meningkatkan ketersediaan $\mathrm{Si}$ tanah dan mengurangi $\mathrm{Al}$, Fe dan $\mathrm{Mn}$ yang bersifat racun bagi akar sehingga daya serap akar lebih baik terhadap hara (Makarim et al., 2007). Selain itu, silikat merupakan anion potensial yang dapat bersaing dengan $P$ dalam menduduki kompleks jerapan sehingga $P$ menjadi tersedia (Setijono,1996). Pemberian pupuk fosfat dapat meningkatkan ketersediaan $\mathrm{P}$ tanah dan lebih mudah diserap oleh tanaman.

Silikat dan $P$ merupakan hara yang dibutuhkan tanaman padi dalam jumlah yang banyak. Si diserap tanaman dalam bentuk $\mathrm{H}_{2} \mathrm{SiO}_{4}$ (Mitani dan $\mathrm{Ma}, 2005$ ), sedangkan fosfor diserap tanaman dalam bentuk $\mathrm{H}_{2} \mathrm{PO}_{4}{ }^{-}$ pada tanah masam (Hanafiah,2007). Silikat berperan dalam melindungi jaringan tanaman sehingga tanaman lebih tahan penyakit, hama dan kekeringan. Silikat melindungi gabah/ beras sejak fase bunga, matang susu hingga matang dari hama penghisap dan jamur jelaga (Makarim et al., 2007). Fosfor berperan dalam pembelahan sel, merangsang perkembangan akar, memperkuat batang, dan pembentukan bunga, biji dan buah (Buckman dan Brady, 1980).

Pemberian silikat dan fosfat diharapkan mampu meningkatkan ketersediaan $\mathrm{P}$ dan $\mathrm{Si}$ di dalam tanah sehingga serapan $\mathrm{P}$ dan $\mathrm{Si}$ tanaman meningkat dan berpengaruh terhadap peningkatan produksi padi gogo di lahan Ultisol. 


\section{BAHAN DAN METODE}

Penelitian dilaksanakan di laboratorium dan di lapangan dari bulan Agustus 2014 sampai Januari 2015 Percobaan lapangan dilakukan di Lahan Ultisol di Desa Pematang Berangan, Kecamatan Rambah, Kabupaten Rokan Hulu, Riau. Analisis sifat kimia tanah sebelum dan setelah penelitian dilakukan di laboratorium Balai Penelitian Tanah Bogor. Sifat kimia tanah awal yang dianalisis meliputi $\mathrm{pH} \mathrm{H}_{2} \mathrm{O}(\mathrm{pH}$ meter), C-organik (Walkley dan Black), N-total (Kjeldahl), nisbah C/N, Ptersedia (Bray I), Kation Basa dapat dipertukarkan (K-dd, Na-dd, Ca-dd, Mg-dd) dan KTK $\left(\mathrm{NH}_{4} \mathrm{OAc}\right.$ pH 7), $\mathrm{KB}$ dan kejenuhan Al $\left(\begin{array}{lll}\mathrm{KCl} & 1 & \mathrm{~N}\end{array}\right)$. Sifat kimia tanah setelah penelitian meliputi $\mathrm{pH}(\mathrm{pH}$ meter), P-tersedia (Bray I) dan Al-dd ( $\mathrm{KCl} 1 \mathrm{~N})$.

Penelitian berupa eksperimen dalam bentuk faktorial menggunakan rancangan acak lengkap. Faktor pertama yaitu silikat terdiri 4 taraf perlakuan $\left(0,50,75\right.$ dan $\left.100 \mathrm{~kg} \mathrm{SiO}_{2} / \mathrm{ha}\right)$ dan pupuk fosfat sebagai faktor kedua terdiri atas 4 taraf $\left(0,36,54\right.$ dan $\left.72 \mathrm{~kg} \mathrm{P}_{2} \mathrm{O}_{5} / \mathrm{ha}\right)$, masing-masing kombinasi diulang tiga kali. Hasil pengamatan setiap parameter dianalisis secara statistik menggunakan analisis ragam dan perbedaan setiap kombinasi perlakuan diketahui dengan uji lanjut Duncan pada taraf $5 \%$.

Padi gogo varietas Situbagendit sebagai tanaman indikator, $\mathrm{Na}_{2} \mathrm{SiO}_{3}$ dan SP36 masing-masing mengandung $29 \% \mathrm{SiO}_{2}$ dan $36 \% \mathrm{P}_{2} \mathrm{O}_{5}$ sebagai sumber silikat dan pupuk Fosfat, Urea dan $\mathrm{KCl}$ sebagai pupuk dasar masing-masing $200 \mathrm{~kg} / \mathrm{ha}$ dan $150 \mathrm{~kg} / \mathrm{ha}$. Silikat diberikan 1 minggu sebelum tanam, sedangkan pupuk fosfat, urea dan $\mathrm{KCl}$ diberikan saat tanam. Padi ditanam dengan jarak $25 \times 25 \mathrm{~cm}$, tiap rumpun dipelihara 3 batang anakan. Parameter yang diamati antara lain tinggi tanaman, jumlah anakan maksimum, jumlah gabah per malai, persentase gabah bernas per malai dan bobot gabah kering per $\mathrm{m}^{2}$.

Data hasil penelitian dianalisis dengan menggunakan program SAS portable 9.1.3 dengan uji lanjut Duncan (DMRT).

\section{HASIL DAN PEMBAHASAN Sifat Kimia Tanah sebelum diberi Perlakuan}

Berdasarkan hasil analisis beberapa sifat kimia tanah sebelum perlakuan, tanah di lokasi penelitian bereaksi sangat masam $(\mathrm{pH}$ $\left.\mathrm{H}_{2} \mathrm{O}=4,40\right)$, kadar C-organik $(2,70 \%)$ dan $\mathrm{N}$ total $(0,27 \%)$ sedang, dengan nisbah $\mathrm{C}$ dan $\mathrm{N}$ sebesar 10,00 yang tergolong rendah. Ketersediaan unsur hara fosfor $(18,70 \mathrm{ppm})$ sedang, K-dd (0,34 me/100g) sedang, dan Na- dd $(0,00 \mathrm{me} / 100 \mathrm{~g})$ sangat rendah, Ca-dd $(1,32$ $\mathrm{me} / 100 \mathrm{~g})$ dan $\mathrm{Mg}$-dd $(0,50 \mathrm{me} / 100 \mathrm{~g})$ dan kapasitas tukar kation $(12,70 \quad \mathrm{me} / 100 \mathrm{~g})$ tergolong rendah, kejenuhan basa $(17 \%)$ sangat rendah dan kejenuhan Al (65\%) tergolong sangat tinggi. Dengan demikian dapat disimpulkan bahwa kesuburan tanah Ultisol di lokasi penelitian tergolong rendah. Hal ini disebabkan tanah Ultisol merupakan tanah mineral yang berkembang dan mengalami pelapukan lanjut disertai pencucian basa-basa ( $\mathrm{Na}, \mathrm{K}, \mathrm{Ca}$ dan $\mathrm{Mg}$ ) dan $\mathrm{Si}$ yang intensif. Adanya pencucian yang intensif menyebabkan tanah bereaksi masam, ketersediaan hara dan kejenuhan basa rendah. Disamping itu suhu yang cukup tinggi menunjang terjadinya pembentukan mineral liat yang didominasi oleh mineral silikat tipe 1:1 dan oksida serta hidroksida Fe dan Al.

Prasetyo dkk, (2000) menyatakan bahwa reaksi tanah Ultisol pada umumnya masam hingga sangat masam $(\mathrm{pH} 5-3,10)$. Nursyamsi dan Suryadi (2000) melaporkan bahwa $\mathrm{pH}$ tanah Ultisol Tapin di Kalimantan Selatan mempunyai $\mathrm{pH}$ 4,70 dan bereaksi sangat masam. Hasil penelitian Herviyanti dkk, (2012) menunjukkan bahwa kejenuhan Al tanah Ultisol Tanjung Pati di Payakumbuh yaitu $64,33 \%$ dan tergolong sangat tinggi.

\section{pH dan Al-dd Tanah setelah diberi Perlakuan}

Tabel 2 menunjukkan bahwa pemberian silikat dan pupuk fosfat meningkatkan $\mathrm{pH}$ dan menurunkan $\mathrm{Al}$-dd tanah. Nilai $\mathrm{pH}$ tertinggi dan nilai Al-dd terendah diperoleh pada pemberian $100 \mathrm{~kg}$ $\mathrm{SiO}_{2}$ dan $36 \mathrm{~kg} \mathrm{P}_{2} \mathrm{O}_{5}$ per hektar, sedangkan $\mathrm{P}$ tersedia tertinggi diperoleh pada pemberian $100 \mathrm{~kg} \mathrm{SiO}{ }_{2}$ dan $72 \mathrm{~kg} \mathrm{P}_{2} \mathrm{O}_{5}$ per hektar. Menurut Nugroho (2009) bahwa pH tanah meningkat disebabkan terjadi hidrolisis air oleh natrium silikat yang diberikan menghasilkan asam silikat dan ion $\mathrm{OH}^{-}$.

Reaksinya sebagai berikut :

$\mathrm{Na}_{2} \mathrm{SiO}_{3}+2 \mathrm{H}_{2} \mathrm{O} \rightarrow \mathrm{H}_{2} \mathrm{SiO}_{3}+2 \mathrm{OH}^{-}+2 \mathrm{Na}^{+}$.

Penurunan Al-dd akibat perlakuan $\mathrm{Si}$ terjadi akibat 2 hal yaitu peningkatan $\mathrm{pH}$ tanah dan reaksi Al dengan Si. Penurunan Al-dd akibat kenaikan $\mathrm{pH}$ terjadi karena peningkatan relatif $\mathrm{OH}^{-}$sehingga $\mathrm{Al}$ menurun aktivitasnya dan membentuk $\mathrm{Al}(\mathrm{OH})_{3}, \mathrm{Al}(\mathrm{OH})^{+}$atau $\mathrm{Al}$ $(\mathrm{OH})^{2+}$ tergantung kondisi tanah.

Misel- $\mathrm{Al}+3 \mathrm{OH}^{-}+3 \mathrm{Na}^{+} \rightarrow \mathrm{Al}(\mathrm{OH})_{3}+$ Misel- $\mathrm{Na}$

Pengaruh $\mathrm{Si}$ secara langsung, terjadi akibat reaksi $\mathrm{Si}$ dengan $\mathrm{Al}$ membentuk senyawa Al-Si :

$2 \mathrm{H}_{4} \mathrm{SiO}_{4}+2 \mathrm{Al}^{3+}+\mathrm{H}_{2} \mathrm{O} \rightarrow \mathrm{Al}_{2} \mathrm{Si}_{2} \mathrm{O}_{5}(\mathrm{OH})_{4}+6 \mathrm{H}^{+}$ (Nugroho, 2009). 
Tabel 1. Nilai Ph dan Al-Dd Tanah Ultisol Setelah Diaplikasi Silikat dan Pupuk Fosfat.

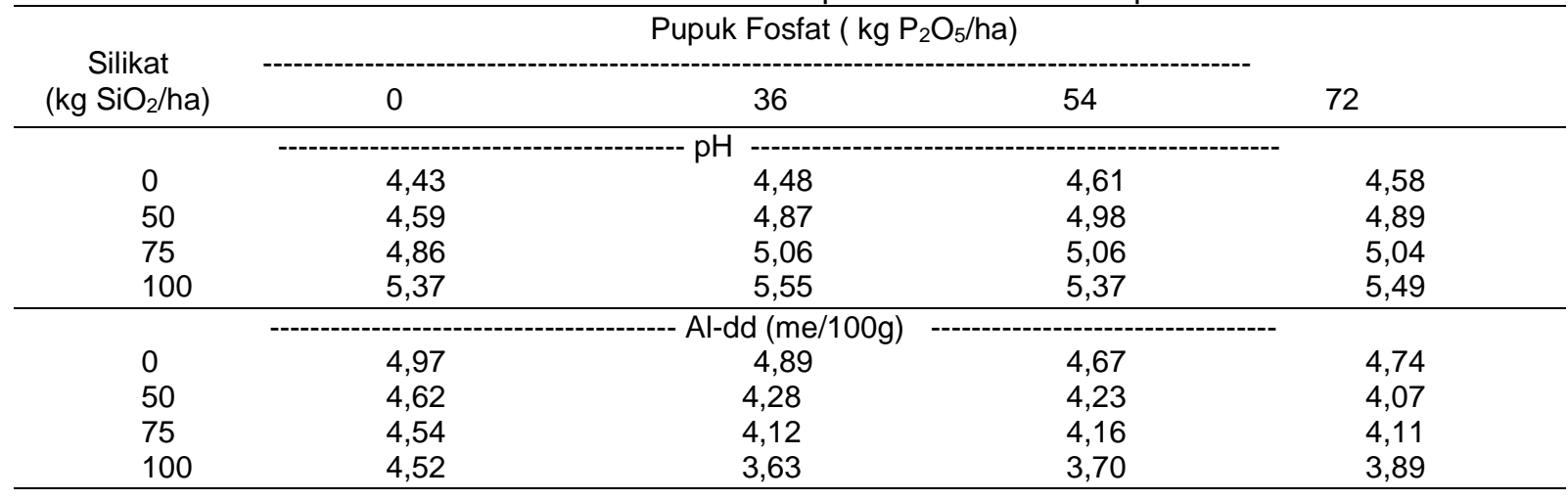

\section{P Tersedia Tanah setelah diberi Perlakuan}

$P$ tersedia tanah meningkat untuk semua perlakuan pada pemberian silikat dan pupuk fosfat dikarenakan silikat dapat menggantikan $\mathrm{P}$ dari pupuk yang diberikan pada kompleks jerapan dan menurunkan konsentrasi ion Al pada larutan tanah sehingga mengurangi fiksasi P oleh Al. Matichenkov dan Calvert (2002) menyatakan bahwa penambahan Si pada tanah akan melalui dua proses. Proses pertama yaitu peningkatan konsentrasi asam monosilikat pada tanah akan menghasilkan pengubahan $\mathrm{P}$ tidak larut menjadi $P$ tersedia bagi tanaman. Fosfor yang tidak tersedia bagi tanaman berhenti pada sisi sematan menyebabkan $\mathrm{P}$ tersemat menjadi tersedia bagi tanaman. Hal ini karena $\mathrm{SiO}_{4}{ }^{4-}$ memiliki elektronegatifitas lebih besar dibandingkan $\mathrm{PO}_{4}{ }^{3-}$ sehingga $\mathrm{SiO}_{4}{ }^{4-}$ dapat menggantikan $\mathrm{PO}_{4}{ }^{3-}$ yang tersemat. Proses kedua yaitu $\mathrm{Si}$ dapat mengikat $\mathrm{P}$ sehingga pelindian $P$ berkurang sekitar 40-90\%. Persamaan reaksinya sebagai berikut:

$2 \mathrm{Al}\left(\mathrm{H}_{2} \mathrm{PO}_{4}\right)_{3}+2 \mathrm{Si}(\mathrm{OH})_{4}+5 \mathrm{H}^{+} \rightarrow \mathrm{Al}_{2} \mathrm{Si}_{2} \mathrm{O}_{5}+$ $5 \mathrm{H}_{3} \mathrm{PO}_{4}+5 \mathrm{H}_{2} \mathrm{O}$

$2 \mathrm{FePO}_{4}+\mathrm{Si}(\mathrm{OH})_{4}+2 \mathrm{H}^{+} \rightarrow \mathrm{Fe}_{2} \mathrm{SiO}_{4}+2 \mathrm{H}_{3} \mathrm{PO}_{4}$ (Matichenkov dan Calvert, 2002).

Hasil penelitian Nugroho (2009) pemberian $\mathrm{Si}$ sebelum pemberian $\mathrm{P}$ akan menyebabkan komplek pertukaran ditempati silikat terlebih dahulu. Pemberian Si sebagai ameliorant dan mendahului perlakuan $\mathrm{P}$ terbukti meningkatkan $P$ tersedia bagi tumbuhan. Penambahan Si sebagai ameliorant setelah perlakuan $\mathrm{P}$ meningkatkan $\mathrm{P}$ tersedia.

Tabel 2. P Tersedia Tanah Ultisol Setelah Diaplikasi Silikat dan Pupuk Fosfat

\begin{tabular}{ccccc}
\hline & \multicolumn{4}{c}{ Pupuk Fosfat $\left(\mathrm{kg} \mathrm{P}_{2} \mathrm{O}_{5} / \mathrm{ha}\right)$} \\
$\begin{array}{c}\text { Silikat } \\
\left(\mathrm{kg} \mathrm{SiO}_{2} / \mathrm{ha}\right)\end{array}$ & 0 & 36 & 54 & 72 \\
\hline & 0 & 26,99 & 29,88 & 30,28 \\
50 & 16,27 & 28,44 & 30,15 & 34,31 \\
75 & 20,69 & 31,49 & 33,90 & 34,90 \\
100 & 21,27 & 35,35 & 34,53 & 36,08 \\
\hline
\end{tabular}

\section{Pertumbuhan dan Produksi Padi Gogo yang Diaplikasi Silikat dan Pupuk Fosfat}

\section{Bobot kering tajuk}

Tabel 3 menunjukkan bahwa pemberian silikat dan pupuk fosfat meningkatkan bobot kering tajuk sekitar 2 $101 \%$ dibanding tanpa perlakuan. Pemberian

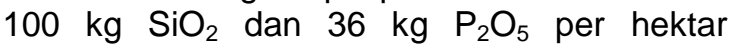
meningkatkan bobot kering tajuk tanaman tertinggi dibanding perlakuan lain. $\mathrm{Hal}$ ini disebabkan pemberian $36 \mathrm{~kg} \mathrm{P}_{2} \mathrm{O}_{5} /$ ha diikuti pemberian silikat $100 \mathrm{~kg} \mathrm{SiO} /$ ha memberikan kecukupan hara $\mathrm{P}$ bagi tanaman. Jumlah hara $\mathrm{P}$ yang cukup di dalam jaringan akan meningkatkan bobot kering tajuk tanaman dikarenakan fosfor merupakan unsur penyusun ADP dan ATP bersama dengan nitrogen. Dalam kondisi demikian maka tanaman akan melakukan aktivitas fotosintesis yang semakin meningkat. Meningkatnya aktivitas fotosintesis akan meningkatkan pembentukan organ tanaman seperti batang dan daun, sehingga bobot kering tajuk tanaman meningkat. Menurut Surowinoto (1983) semakin banyak $P$ yang dapat diserap maka pertumbuhan akan semakin baik yang ditunjukkan dengan berat kering tanaman yang tinggi. 
Tabel 3. Bobot Kering Tajuk Tanaman Padi Gogo Umur 48 Hari Setelah Tanam Pada Lahan Ultisol yang Diaplikasi Silikat dan Pupuk Fosfat

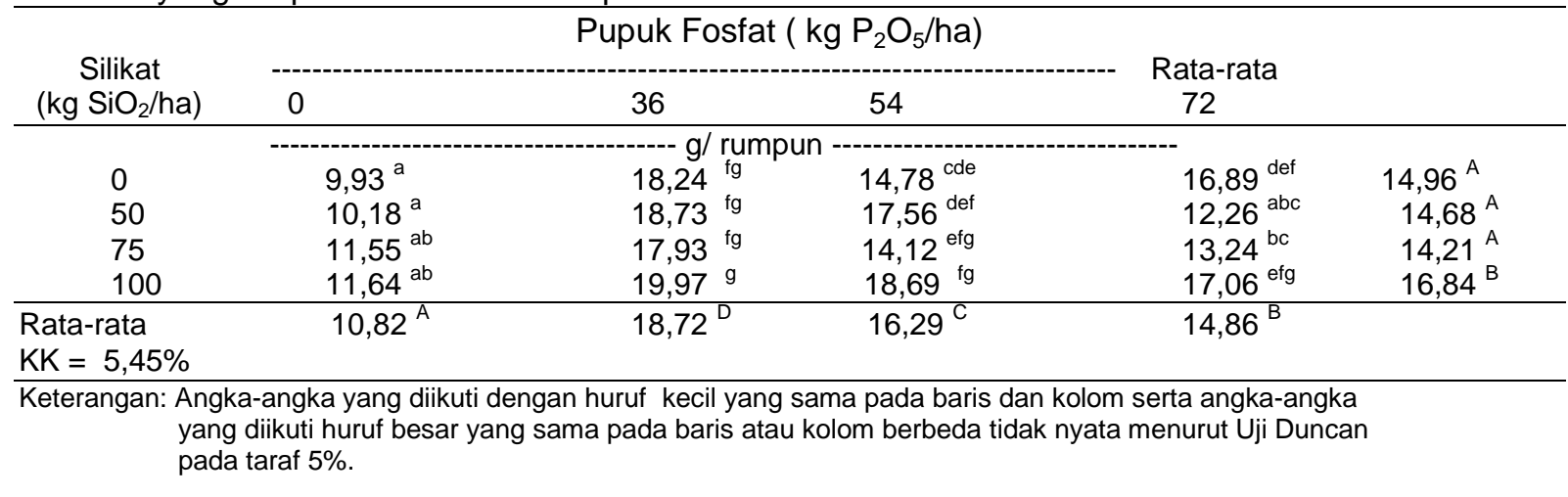

\section{Bobot kering akar}

Tabel 4 menunjukkan bahwa pemberian $100 \mathrm{~kg} \mathrm{SiO} 2$ dan $36 \mathrm{~kg} \mathrm{P}_{2} \mathrm{O}_{5}$ per hektar meningkatkan bobot kering akar tanaman tertinggi dibanding perlakuan lain. Bobot kering akar meningkat sekitar 0,02-1,88 g/rumpun dibanding tanpa pemberian silikat dan pupuk fosfat. Hal ini disebabkan adanya peningkatan $\mathrm{P}$ tersedia dan penurunan Al-dd tanah setelah diaplikasi silikat dan pupuk fosfat. $P$ tersedia tanah meningkat maka serapan $P$ tanaman juga meningkat. Peningkatan serapan $\mathrm{P}$ akan meningkatkan bobot dan volume akar dikarenakan fosfor dibutuhkan tanaman dalam proses metabolisme dan fisiologis.
Fosfor (P) dapat menstimulir pertumbuhan dan perkembangan perakaran tanaman karena $P$ berperan dalam metabolisme sel dan sebagai aktivator beberapa enzim (Nyakpa et al.,1985; Prasad dan Power, 1997). Soepardi (1983) menyatakan bahwa peranan fosfor bagi tanaman adalah membantu perkembangan akar dan akar rambut, mengimbangi pengaruh kelebihan nitrogen, serta memperkuat batang sehingga tidak mudah rebah. Sutoro et al., (1988) menyatakan bahwa kekurangan unsur $\mathrm{P}$ menyebabkan perakaran tanaman menjadi dangkal dan penyebarannya terbatas serta batangnya menjadi lemah.

Tabel 4. Bobot kering akar tanaman padi gogo umur 48 hari setelah tanam pada lahan Ultisol yang diaplikasi silikat dan pupuk fosfat

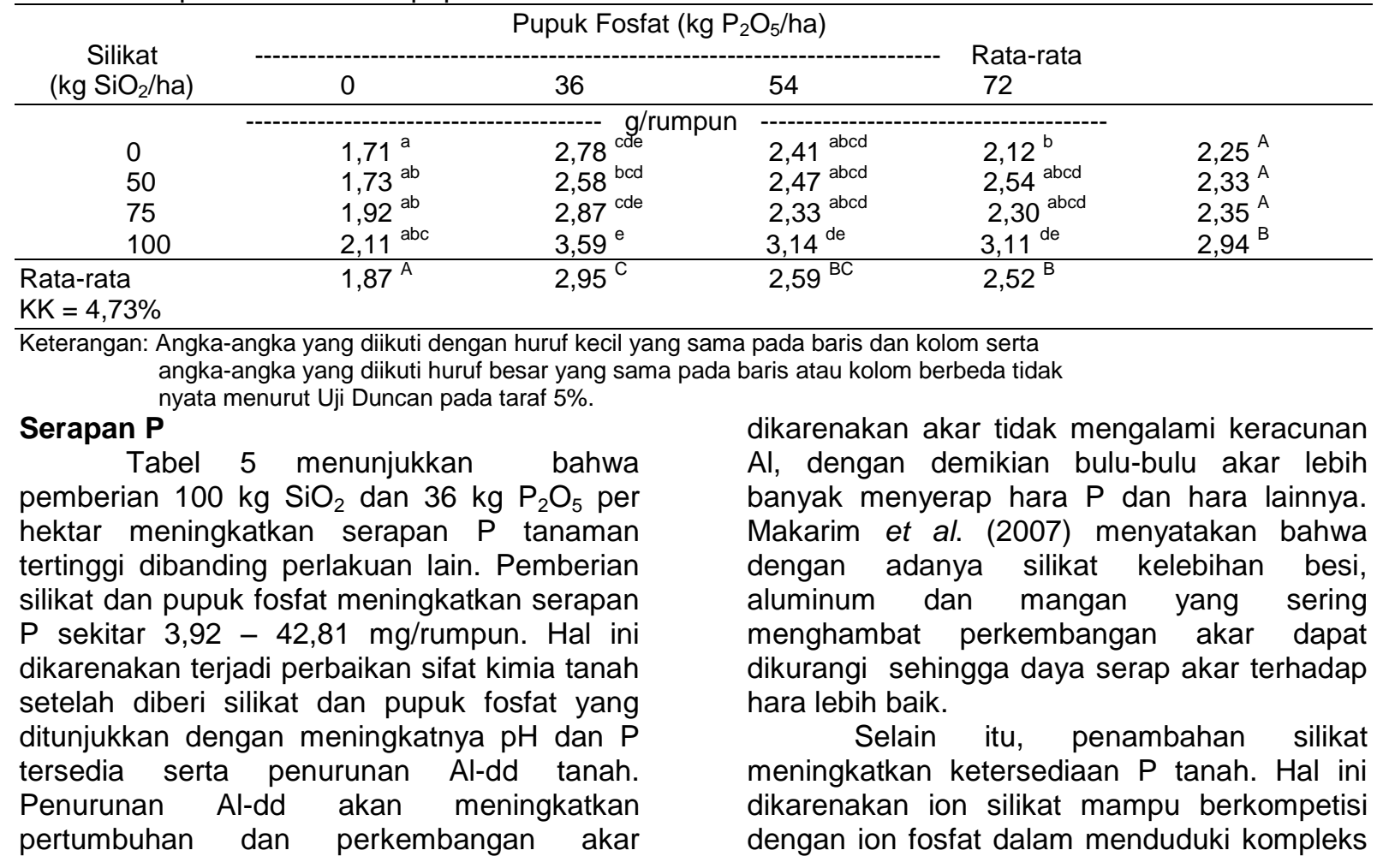


jerapan. Dengan demikian serapan $\mathrm{P}$ tanaman akan meningkat karena $\mathrm{P}$ tersedia tanah meningkat dan dapat diserap oleh tanaman. Sanchez dan Uehara (1980) menyatakan bahwa pemberian silika dapat meningkatkan kadar P di dalam tanah menjadi bentuk yang lebih tersedia bagi tanaman. Menurut Bolt dan Bruggenwert (1978) hal ini disebabkan karena ion silikat $\left(\mathrm{SiO}_{4}{ }^{4-}\right)$ lebih kuat terjerap dibandingkan dengan ion fosfat $\left(\mathrm{PO}_{4}^{3-}\right)$.

Tabel 5. Serapan P oleh Padi Gogo pada Lahan Ultisol Setelah Diaplikasi Silikat dan Pupuk Fosfat

\begin{tabular}{|c|c|c|c|c|c|}
\hline \multirow{2}{*}{$\begin{array}{c}\text { Silikat } \\
\left(\mathrm{kg} \mathrm{SiO}_{2} / \mathrm{ha}\right) \\
\end{array}$} & \multicolumn{4}{|c|}{ Pupuk Fosfat (kg $\left.\mathrm{P}_{2} \mathrm{O}_{5} / \mathrm{ha}\right)$} & \multirow{2}{*}{ Rata-rata } \\
\hline & 0 & 36 & 54 & 72 & \\
\hline $\begin{array}{l}0 \\
50 \\
75 \\
100\end{array}$ & $\begin{array}{l}20,56^{a} \\
26,32^{a} \\
27,03^{a} \\
24,48^{a}\end{array}$ & $\begin{array}{l}-\mathrm{mg} / \mathrm{rur} \\
43,13^{\mathrm{b}} \\
52,53^{\mathrm{bc}} \\
47,33^{\mathrm{b}} \\
63,37^{\mathrm{c}}\end{array}$ & $\begin{array}{l}44,67^{\mathrm{b}} \\
47,42^{\mathrm{b}} \\
48,33^{\mathrm{b}} \\
58,72^{\mathrm{bc}}\end{array}$ & $\begin{array}{l}47,40^{b} \\
46,48^{b} \\
47,12^{b} \\
56,45^{b c}\end{array}$ & $\begin{array}{r}38,94^{\mathrm{A}} \\
43,19^{\mathrm{A}} \\
42,45^{\mathrm{A}} \\
50,75^{\mathrm{B}}\end{array}$ \\
\hline $\begin{array}{l}\text { Rata-rata } \\
\mathrm{KK}=6,34 \%\end{array}$ & $24,59^{\mathrm{A}}$ & $51,59^{\mathrm{B}}$ & $49,78^{B}$ & $49,28^{B}$ & \\
\hline
\end{tabular}

\section{Serapan Si}

Tabel 6 menunjukkan bahwa serapan Si tertinggi diperoleh pada pemberian silikat $100 \mathrm{~kg} \mathrm{SiO} 2$ dan pupuk fosfat $36 \mathrm{~kg} \mathrm{P}_{2} \mathrm{O}_{5}$ per hektar yaitu $413,85 \mathrm{mg} /$ rumpun. Serapan $\mathrm{Si}$ tanaman meningkat sekitar 28 - $284 \mathrm{mg} /$ rumpun dibanding tanpa perlakuan. Hal ini disebabkan tanaman padi merupakan tanaman akumulator Si yang membutuhkan silikat dalam jumlah yang banyak selama pertumbuhannya. Makarim et al. (2007) menyatakan bahwa serapan silikat pada tanaman padi sebanyak 6 kali serapan $\mathrm{K}, 10$ kali serapan $\mathrm{N}, 20$ kali serapan $\mathrm{P}_{2} \mathrm{O}_{5}$ dan 30 kali serapan Ca. Takahashi (1995) menyatakan bahwa silikat banyak terdapat pada lapisan epidermis di daun, pelepah daun dan batang. Ma dan Takahashi (2002) menyatakan bahwa silikat pada padi berperan dalam meningkatkan kekuatan jaringan pada batang, daun dan akar. Si juga meningkatkan kekuatan mekanik dinding sel dan melindungi buah padi dari serangan hama seperti penggerek batang, wereng coklat, wereng hijau dan hama punggung putih.

Tabel 6. Serapan Si oleh Padi Gogo pada Lahan Ultisol Setelah Diaplikasi Silikat dan Pupuk Fosfat

\begin{tabular}{|c|c|c|c|c|c|}
\hline & & Pupuk Fo & $\left.\mathrm{P}_{2} \mathrm{O}_{5} / \mathrm{ha}\right)$ & & \\
\hline$\left(\mathrm{kg} \mathrm{SiO}_{2} / \mathrm{ha}\right)$ & 0 & 36 & 54 & 72 & Rata-rata \\
\hline $\begin{array}{c}0 \\
50 \\
75 \\
100\end{array}$ & $\begin{array}{c}129,85^{\mathrm{a}} \\
157,45^{\mathrm{ab}} \\
186,90^{\mathrm{abc}} \\
240,01^{\mathrm{bcd}}\end{array}$ & $\begin{array}{l}209,02^{\text {bc }} \\
270,19^{\text {cd }} \\
362,17^{\text {ef }} \\
413,85^{f}\end{array}$ & $\begin{array}{c}\mathrm{mg} / \text { rumpur } \\
169,68^{\mathrm{ab}} \\
227,77^{\mathrm{bcd}} \\
296,09^{\mathrm{de}} \\
391,62^{\mathrm{f}}\end{array}$ & $\begin{array}{l}189,80 \text { abc } \\
217,56 \text { bcd } \\
244,18^{\text {bcd }} \\
373,94^{\text {ef }}\end{array}$ & $\begin{array}{l}174,59^{A} \\
218,24^{B} \\
272,33^{C} \\
354,85^{D}\end{array}$ \\
\hline $\begin{array}{l}\text { Rata-rata } \\
\mathrm{KK}=9,72 \%\end{array}$ & $178,55^{\mathrm{A}}$ & $313,81^{C}$ & $271,29^{B}$ & $256,47^{B}$ & \\
\hline
\end{tabular}

\section{Kesimpulan}

Pemberian silikat dan pupuk fosfat meningkatkan $\mathrm{pH}$ dan $\mathrm{P}$ tersedia tanah, bobot kering tajuk dan akar tanaman, serapan $\mathrm{P}$ dan Si. Pemberian silikat dan pupuk fosfat pada taraf $100 \mathrm{~kg} \mathrm{SiO}$ dan $36 \mathrm{~kg} \mathrm{P}_{2} \mathrm{O}_{5}$ per hektar memberikan nilai tertinggi terhadap $\mathrm{pH}$ tanah $(5,55)$, bobot kering tajuk (19,97 g/rumpun), bobot kering akar (3,59 g/rumpun), serapan $\mathrm{P}$ (63,37 $\mathrm{mg} /$ rumpun) dan serapan $\mathrm{Si}(413,85$ $\mathrm{mg} /$ rumpun) dibanding perlakuan lainnya.
Bolt, G.H and Bruggenwert, M.G.M. 1978. Soil Chemistry. A. Basic Elements Elsevier Scientific. Publishing. Company.

Buckman, O.H and N.C. Brady. 1980. The Nature And Properties of Soil. Macmillan Co. Inc. New York.

Hardjowigeno, S. 2003. Ilmu Tanah. Akade mika Presindo. Jakarta. 286 hal.

Hanafiah, KA. 2007. Dasar-Dasar IImu Tanah. Jakarta: Raja Grafindo Persada.

Herviyanti, Ahmad, F., Sofyani, R., Darma wan, Gusnidar, dan Saidi, A. 2012. 
Pengaruh Pemberian Bahan Humat dari Ekstrak Batubara Muda (Subbituminus) dan Pupuk P terhadap Sifat Kimia Ultisoll serta Produksi Tanaman Jagung. Jurnal Solum 9 (1): $15-24$

Makarim, A. K., E. Suhartatik, A., Kartohar djono. 2007. Silikon: Hara Penting pada Sistem Produksi Padi. Iptek Tanaman Pangan 2 (2) : 195-204.

Ma, J. F. And Takahashi, E. 2002. Soil, Ferti lizer and Plant Silicon Research In Japan. Elsevier Science B. V. Amsterdam.

Matichenkov, V. V. \& D. V. Calvert. 2002. Silicon as a beneficial element for sugarcane. Journal American Society of Sugarcane Technologiest 22 : 2130.

Mitani, N and Ma, J. F. 2005. Uptake system of silicon in different plant species. Faculty of Agriculture. Kagawa University. Journal of Experimental Botany 56(414) : 1255-1261.

Nugroho, B. 2009. Peningkatan Produksi Padi Gogo Dengan Aplikasi Silikat Dan Fosfat Serta Inokulasi Fungi Mikoriza Arbuskular Pada Ultisol. Tesis. Sekolah Pascasarjana. IPB. Bogor.

Nursyamsi, D dan Suryadi, M.E. 2000. Pengaruh Drainase Terputus dan Pemupukan terhadap $\mathrm{pH}$, Eh, dan Mn, pada Sawah Baru di Ultisol Bandar Abung (Lampung) dan Tapin (KalSel). Jurnal IImu Tanah dan Lingkungan 3 (2): $8-17$.

Nyakpa, M.Y. Lubis, A.M. Pulung, M.A. Amroh, A.G, Munawar, A. Hong, G.B dan N. Hakim. 1988. Kesuburan Tanah. Universitas Lampung,S Bandar Lampung. 294 hal.

Prasad, R dan Power, J.F. 1997. Soil Fertility Management for Sustainable Agriculture. New York: Lewis Publishes.

Prasetyo, B. H., H. Sosiawan, and S. Ritung. 2000. Soil of Pametikarata, East Sumba: Its Suitability and Constraints for Food Crop Development. Indon. Journal. Agric. Sci. 1(1): 1 - 9.

Sanchez, P.A and Uehara, G. 1980. Management Considerations for Acid Soils with Phophorus Fixation Capacity. In . The Rule of Phosphorus In Agriculture. ASA - CSSA- SSSA. Madison. hal 471-509.

Setijono, S.1996. Intisari Kesuburan Tanah. IKIP. Malang.
Soepardi, G. 1983. Sifat Dan Ciri Tanah. Jurusan Tanah. Fakultas Pertanian. IPB. Bogor. 591 hal.

Subandi, 2007. Teknologi Produksi dan Strategi Pengembangan Kedelai pada Lahan Kering Masam. Iptek Tanaman Pangan. Vol 2, No.1.

Surowinoto. 1983. Tanaman Padi Sawah. Bogor: Institut Pertanian Bogor. 78 hal.

Sutoro, V., Soeleman dan Iskandar. 1988. Budidaya Tanaman Jagung. Pusat Penelitian dan Pengembangan Tanaman Pangan. Bogor.

Takahashi, E.1995. Uptake and Phhysiological Functions of Silica. p. $420-433$. In Matsuo, T, K. Kumazawa, R. Ishii , K. Ishihara, and $\mathrm{H}$. Hirata (Eds.). Science of Rice Plant, Volume Two, Physiology. Food and Agriculture Research Center, Tokkyo. 